\title{
KROVNO ZDRUŽENJE ZA IZOBRAŽEVANJE ODRASLIH \\ Okrepiti vpliv civilne družbe in partnersko sodelovanje z državo
}

Zadnja leta se vse bolj kaže, da smo v Sloveniji pri razvijanju izobraževanja odraslih in pri oblikovanju strategije njegovega razvoja 'pozabili' ali preveč puščali ob strani civilno družbo. S tem smo po nepotrebnem zanemarili zelo pomembno sestavino razvoja današnje moderne ali postmoderne družbe, razvoj pa še naprej ali celo čedalje bolj prepuščamo milosti ali nemilosti države.

V prispevku želim ta problem, ki po mojem mnenju zasluži mnogo več kot le občasno pozornost $\mathrm{v}$ razpravah stanovskih prostovoljskih društev ali ožjega kroga strokovnjakov - v zadnjih letih so bile takšne razprave nekajkrat spodbujene in tudi izpeljane, a se do zdaj v praksi še ni nič spremenilo -, nekoliko podrobneje in bolj poglobljeno predstaviti.

\section{PARTNERSTVO - POMEMBEN DEL NACIONALNIH POLITIK IN STRATEŠKIH RAZVOJNIH NAČRTOV}

$\mathrm{Ni}$ potrebno posebej utemeljevati, da je področje vzgoje in izobraževanja med tistimi področji družbenega delovanja in upravljanja, pri katerih si želi država zagotoviti kar največ možnosti vplivanja. Za državo je to pomembno, saj lahko odločujoče pripomore $\mathrm{k}$ uveljavljanju pomembnih nacionalnih ciljev in udejanjanju začrtane nacionalne politike in strategije, tako celotne kot tudi tiste na posameznih področjih razvoja, kot so gospodarstvo, kultura, socialni razvoj, okolje, varnost, kmetijstvo, znanost in tehnologija ter bolj ali manj tudi vsa druga specifična področja družbenega delovanja. Povečana pozornost države za razvoj nekega področja ima tako dobre kot tudi neugodne posledice, $\mathrm{Da}$ se povečani interes države zrcali $\mathrm{v}$ sistematični skrbi države za razvoj področja, je dobro, saj pomeni, da skrbi za njegovo sistemsko urejenost in organiziranost ter ustrezno zadovoljevanje potreb uporabnikov (prebivalstva, izvajalcev itn.). To dosega predvsem s svojimi temeljnimi sredstvi in orodji - urejanjem vprašanj upravljanja, zakonodaje, financiranja, razvojne infrastrukture ipd.; $\mathrm{z}$ vsemi temi sredstvi zagotavlja ustrezne materialne in druge pogoje za delovanje področja. Vpliv države lahko postane neugoden takrat, ko država pojmuje in udejanja svojo vlogo in moč preveč togo, birokratsko, avtoritarno ipd. ali pomanjkljivo, in tako duši pobude, ustvarjalnost, spontanost, specifične potrebe, avtonomijo in druge značilnosti kakovostnega delovanja področja v praksi.!

Seveda nimam namena $\mathrm{v}$ tem prispevku pogrevati ц̌e dobro znane stvari, da državi 'zmanjkuje sape' - najpogosteje se pri tem izgovarja, da ni denarja -, ko gre za izo- 


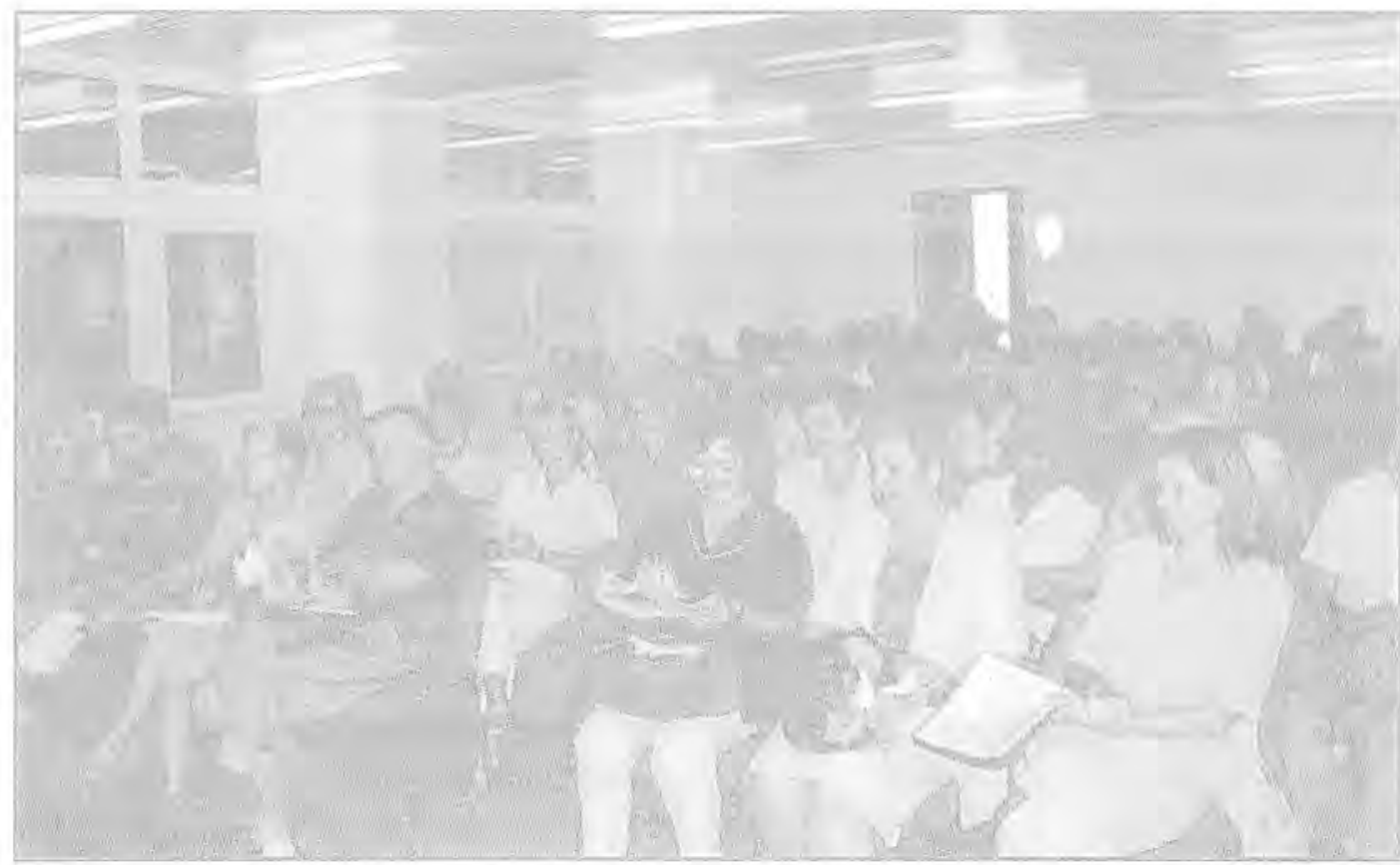

braževanje odraslih. Če tej trditvi natančneje 'pogledamo pod kožo', bomo videli, da jo pogojuje splet vzrokov - od tradicionalnih pojmovanj o vzgoji in izobraževanju, da pripadata predvsem otrokom in mladini, prek nerazvitega upravljanja, pomanjkljive zakonodaje, nejasnosti o strukturi in obsegu omrežja, nezadostno razvite infrastrukture do nerazvitega zavedanja o vlogi in možnostih izobraževanja odraslih ter napačno oblikovane zavesti o njem. Gotovo pa se tudi ne moremo tolažiti z možnostjo, da je prav, če se najprej poskrbi za izobraževanje otrok in mladine, ko pa to zadovoljivo uredimo (!), se lotimo izobraževanja odraslih. Je sploh mogoče urejati eno področje, ne da bi hkrati urejali tudi drugega?! Danes spoznavamo, da področja vzgoje in izobraževanja ne moremo urejati, ne da bi sprejeli načela in strategijo vseživljenjskosti učenja, ki jo bolj ozaveščene nacionalne politike že včlenjujejo $\mathrm{v}$ svoje nacionalne razvojne programe za področje vzgoje in izobraževanja (glej npr. Jelenc 1999 in 2000).

Zato se čedalje več razmišlja tako o tem, kdo in kako bi lahko pomagal državi, da bi lahko ustrezneje zadovoljila vse potrebe, kot tudi, kako bi lahko država pri skrbi za razvoj vzgoje in izobraževanja načrtno spodbudila in organizirala še druge možnosti - partnerje, vire financiranja, človeške vire, materialne možnosti in druge. To velja za urejanje tako začetnega kot tudi nadaljevalnega izobraževanja. Ugotavlja se, denimo, da tudi pri začetnem izobraževanju zdajšnji sistemi javnega financiranja niso optimalni in predvsem, da niso prilagojeni novim in povečanim potrebam. ${ }^{2}$

Bistvo navedenih ugotovitev je, da nadaljnjega optimalnega razvoja ne moremo zagotoviti s takšno vlogo države, kakršna je prevladovala $\mathrm{v}$ preteklosti in je povečini značilna za nacionalne politike še zdaj. Na takšno usmeritev je že v času znane svetovne krize izobraževanja $v$ šestdesetih letih prejšnjega stoletja začel opozarjati Unesco (Foure 1972), izrazito potrditev je
Na celotnem področju izobrażevanja bo potrebno vzpostaviti partnerski odnos. 
dobila sredi devetdesetih let $\mathrm{z}$ znanim ministrskim srečanjem OECD v Parizu (1996), zelo jasna in odločna stališča pa so se izkristalizirala tudi na zadnji od velikih svetovnih konferenc Unesca o izobraževanju odraslih v Hamburgu leta 1997. V koněnih dokumentih s te konference, Hamburški deklaraciji in Akcijskem načrtu za prihodnost (CONFINTEA 1998), najdemo tele poglavitne ugotovitve:

\section{Hamburška deklaracija (CONFINTEA:} 4, tč. 8 )

- "Ob novih partnerstvih, ki se porajajo med javnimi in zasebnimi sektorji in lokalnimi skupnostmi, se vloga države spreminja. Država ni samo tista, ki zagotavlja izobraževanje odraslih, temveč je svetovalka, vlagateljica in agencija, ki spremlja ..."

- Ukrepe za razvoj in pomoč posameznikom, da bi jim omogočili zadovoljitev potreb in večjo dostopnost do izobraževanja, sprejemajo skupno vlade in socialni partnerji.

- "V vladah izobraževanje odraslih ni omejeno zgolj na ministrstvo za izobraževanje; vsa ministrstva so zadolžena za pospeševanje izobraževanja odraslih. Bistveno je tudi sodelovanje med njimi."

\section{Akcijski načrt}

- Razvoj učenja odraslih zahteva sodelovanje med oddelki vlad, med vladnimi in nevladnimi organizacijami, delodajalci, sindikati, univerzami in raziskovalnimi instituti ter središči, javnimi občili, civilno družbo in združenji na lokalni ravni, med izobraževalci odraslih in samimi odraslimi učenci. (CONFINTEA: 12, tč. 3).

- "Učenje odraslih se je razraslo tako $v$ širino kot tudi v globino, postalo je zahteva na delovnem mestu, doma in v skupnosti ... ". Podpisniki deklaracije se zavzemajo za doseganje večjega sodelovanja skupnosti, pri tem pa poudarjajo vlogo nevladnih organizacij. (N. d.: 14-16, tč. 9, 12, 14).

- Dostopnost in večjo kakovost izobraževanja lahko zagotovi sodelovanje vseh partnerjev tudi pri sprejemanju zakonodaje, politike in drugih mehanizmov. (N. d.: 18, tč. 18).

- Nova vloga države in socialnih partnerjev se kaže v tem, da si priznavajo medsebojno odgovornost, ustvarjajo potrebno finančno in upravno podporo, utrjujejo medsebojne krovne zveze, dopolnjujejo delo vlad $\mathrm{z}$ udeležbo civilne družbe. (N. d.: 21, tč. 23).

- Vlade naj bi podprle organizacije civilne družbe in jih ustrezno financirale. (N. d.: 21 , tč. 23b).

- Izjemna decentralizacija narave učenja odraslih in sodelovanje čedalje številnejših in različnejših partnerjev zahtevajo, da se oblikujejo na tem področju zelo gibljivi mehanizmi in strategije. (N. d.: 4l, tč. 55).

- Da bi različni dejavniki in ključni partnerji,

Primerjalna raziskava, ki jo je v letu 1999-2000 opravilo Andragoško društvo Slovenije (Jelenc, 2000), je pokazala, da imajo domala vse evropske države krovno zvezo, ki je pomemben dejavnik razvoja izobraževanja odraslih v državi. Modeli organiziranosti se med seboj sicer razlikujejo, a po poglavitnih značilnostih jih lahko $v$ večini primerov uvrstimo $v$ dva modela: a/ krovna zveza, ki vključuje le organizacije in skupnosti, ne pa posameznikov; b/ krovna zveza, ki vključuje tako organizacije in skupnosti kot tudi posameznike; tretji model je krovna zveza, ki vključuje le posameznike, vendar imajo tak model organiziranosti po naših podatkih le v treh državah, med katerimi je tudi Slovenija. Za oba prevladujoča modela je med drugim značilno, da opravljata svoje naloge $\mathrm{z}$ ustrezno profesionalno organiziranostjo in so za svoje delovanje odgovorne predvsem svojim članicam. 
ki delujejo na tem področju, delovali čim učinkoviteje, jih je potrebno usklajevati in spremljati njihovo delovanje; to velja tudi za vpeljevanje in spremljanje politike (prav tam).

V Sloveniji zdaj nimamo krovne zveze delujočih organizacij na področju izobraževanja odraslih. Potencialno najbliže sta ji Andragoško društvo Slovenije (ADS) in Andragoški center Slovenije (ACS).

Andragoško društvo Slovenije (ADS) je stanovsko društvo za področje izobraževanja odraslih in andragogike. Združuje posameznike, ki se bodisi neposredno ukvarjajo $\mathrm{z}$ izobraževanjem odraslih bodisi se zanimajo za to področje in dejavnost; po zdajšnjih določilih statuta in pravil ADS ni predvideno, da bi se vanj včlanjevale tudi organizacije. Je društvo nacionalnega pomena in zajema vse vrste dejavnosti in vse razsežnosti izobraževanja odraslih. Sprememba iz zdajšnje stanovske $v$ krovno zvezo bi zahtevala korenito in sistematično reorganizacijo ADS. O morebitni reorganizaciji so razpravljali delegati na letni skupščini ADS dne 1, 6, 2001.

Andragoški center Slovenije (ACS) je bil ustanovljen kot najširša profesionalna organizacija za razvijanje in pospeševanje razvoja izobraževanja odraslih, danes pa deluje predvsem v vlogi razvojne in svetovalne organizacije. Takšen status ACS-u ne omogoča, da bi udejanjal vse interese (tako strokovne kot tudi tiste, ki nastajajo v civilni družbi) na področju izobraževanja odraslih.

Druge delujoče strokovne institucije (npr. visokošolske ustanove, Zavod za šolstvo, Center za poklicno izobraževanje itn.) kot tudi izvajalske organizacije (ljudske univerze, izobraževalni centri $\mathrm{v}$ podjetjih, zasebne izobraževalne ustanove itn.) so posamično prešibke, da bi lahko pomembneje vplivale na stanje in razvoj izobraževanja odraslih. Prav tako pa niso dovolj razviti sicer številni subjekti in organizacije civilne družbe tako tistih, ki se profesionalno ukvarjajo $\mathrm{z}$ izobraževanjem odraslih (npr. zveza ljudskih univerz, društva izobraževalcev odraslih $v$ šolah, podjetjih $\mathrm{v}$ gospodarstvu, zasebnih podjetjih itn.), kot tudi mnogih prostovoljskih organizacij, ki vključujejo v svoje programe izobraževanje svojih članov.

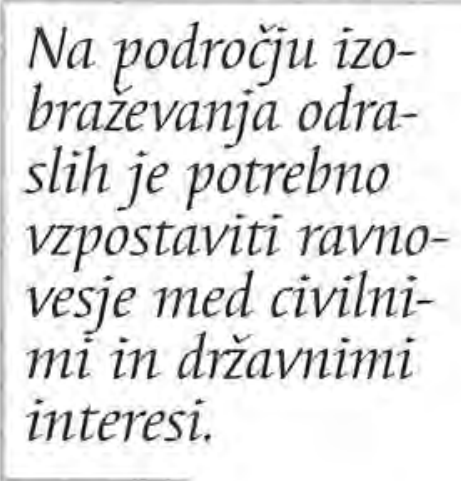

\section{ZASNOVA KROVNE ZVEZE ZA IZOBRAŽZEVANJE ODRASLIH V SLOVENIJI}

$\mathrm{Z}$ ustanovitvijo krovne zveze po enem od obeh opisanih prevladujočih modelov, ki jih imajo $v$ drugih evropskih državah, bi tudi v Sloveniji dobili dovolj močan strokovni in družbeni subjekt, ki bi lahko vzpostavil ravnotežje.

Izhod bi lahko bil čimprejšnja ustanovitev krovne zveze za izobraževanje odraslih.

$\mathrm{Na}$ kratko bi lahko opredelili cilje njene ustanovitve in delovanja takole;

- Z ustanovitvijo krovne zveze bi omogočili in okrepili povezovanje delujočih organizacij na področju izobraževanja odraslih, tako profesionalnih kot tudi neprofesionalnih;

- S povezovanjem in sodelovanjem številnih in raznovrstnih subjektov - bodisi organizacij in skupin bodisi posameznikov --, ki delujejo na tem področju, bi povečali njihov vpliv in tako zboljšali položaj in razvoj tako izobraževanja odraslih v Sloveniji kot tudi njihov položaj in uspešnost.

Potencialni člani in članice takšne krovne zveze bi bili: ${ }^{3}$

- krovne zveze (društva, združenja) iz- 
vajalskih strokovnih organizacij za izobraževanje odraslih (npr. ljudske univerze, zasebne izobraževalne organizacije, šolske enote, izobraževalna središča itn.);

- Andragoško društvo Slovenije kot najsplošnejša stanovska asociacija, združujoča posameznike, ki strokovno delujejo na področju izobraževanja odraslih in andragogike $v$ Sloveniji, ter tudi kot organizacija, ki je načelno že podprla predlog za ustanovitev krovne zveze;

- posamezne organizacije za strokovno, razvojno in znanstveno-raziskovalno delo na področju izobraževanja odraslih, ki delujejo bodisi kot samostojne organizacije in niso povezane $\mathrm{v}$ delujoče asociacije za izobraževanje odraslih (npr. Andragoški center Slovenije, Center RS za poklicno izobraževanje, Vitra - Center za trajnostni razvoj, Univerza za tretje življenjsko obdobje) bodisi kot enote večjih organizacij (npr. Oddelek za pedagogiko in andragogiko ali Katedra za andragogiko na Filozofski fakulteti, Center za izobraževanje na daljavo na Ekonomski fakulteti, Zavod za šolstvo RS, enote drugih fakultet ter višjih in visokih šol itn.);

- asociacije posebnih oblik in načinov dejavnosti izobraževanja odraslih ali razvojnih projektov (npr. študijski krožki, projektno učenje za mlade, središč za samostojno učenje, borza znanja itn.);

- druge strokovne krovne zveze (združenja), ki vključujejo izobraževanje odraslih kot pomembno dejavnost pri udejanjanju svojih ciljev in interesov (npr. Zveza društev kadrovskih delavcev, Društvo defektologov Slovenije s sekcijami za različne osebe s posebnimi potrebami, npr, $\mathrm{z}$ motnjami $\mathrm{v}$ duševnem in telesnem razvoju, telesno invalidni, slepi in slabovidni, gluhi in naglušni itn.);

- različne prostovoljske krovne zveze in organizacije, ki pomembno vključujejo izobraževanje odraslih pri udejanjanju svojih ciljev in interesov; to so lahko humanitarne organizacije (npr. bolnikov, invalidov itn.), organizacije za pomoč ljudem (oblike socialne pomoči, prostovoljskega dela, zveza družin, klubi za boj proti alkoholizmu in odvisnostim itn.), ljubiteljske organizacije (s področja umetnosti, športa, ročnih del itn.) ter različne druge;

- posamezniki, bodisi tisti, ki se ukvarjajo z izobraževanjem odraslih, bodisi drugi zainteresirani.

Ob dovolj velikih in prepričljivo izraženih potrebah, interesih in podpori se lahko krovna zveza ustanovi takoj kot organizacija $v$ ustanavljanju. Za opredelitev načinov njenega delovanja in organiziranosti pa je nedvomno potrebno oblikovati projektno skupino, ki bi imela nalogo, da strokovno pripravi vse potrebno za delovanje krovne zveze in pred tem razreši nekatera odprta vprašanja, ki

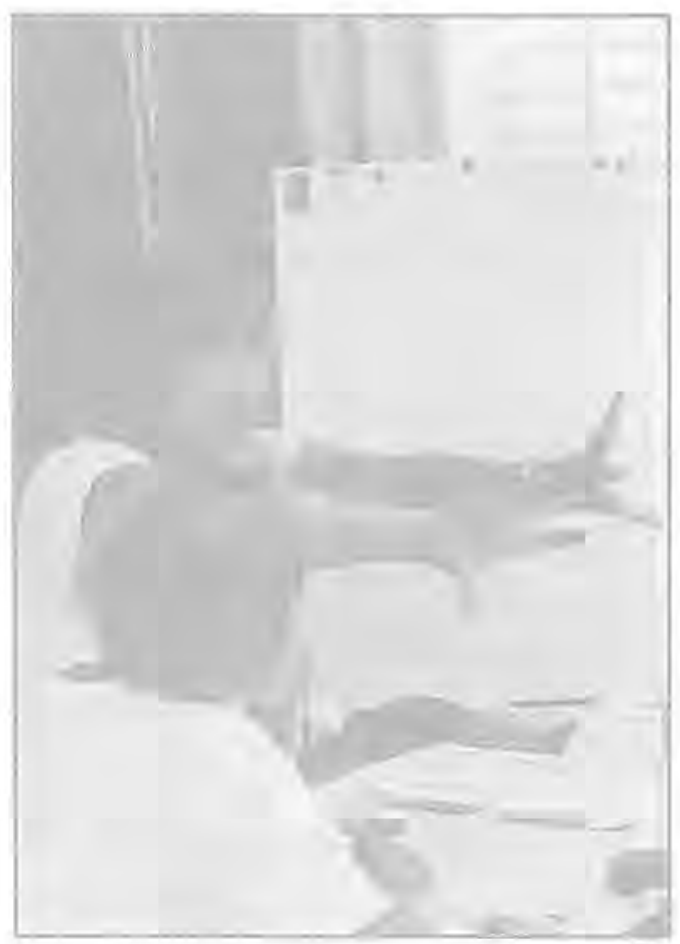


zahtevajo posebno proučitev vprašanj, kot so status organizacije, program, način delovanja, financiranje, odnosi med člani, sedež itn. O teh vprašanjih lahko za zdaj hipotetično rečemo tole:

- Status organizacije mora zagotoviti samostojnost krovne zveze, možnost enakopravnega delovanja različnih zainteresiranih subjektov (organizacij, krovnih zvez, posameznikov), tako profesionalnih kot tudi prostovoljskih, vladnih in nevladnih; za učinkovitejšse delo naj bi imela možnost za oblikovanje projektnih skupin in/ali notranjih organizacijskih enot (npr. za strategijo in razvoj, financiranje organizacij in programov izobraževanja odraslih, informacijsko dejavnost, pravna vprašanja, promocijo in stike $\mathrm{z}$ javnostmi, mednarodno sodelovanje, raziskovalni center ali institut itn.).

- Program mora ustrezati interesom in potrebam vseh članic, ki se odločijo med naslednjimi nalogami in dejavnostmi: deluje kot koordinacijsko telo, krepi sodelovanje članic in jih pravno zastopa ter po potrebi usklajuje njihovo dejavnost; skrbi za šrjenje ponudbe formalnega in neformalnega izobraževanja; sodeluje pri oblikovanju nacionalne politike in strategije izobraževanja odraslih; sodeluje pri razvijanju pravnih podlag za izobraževanje odraslih; daje pobude za razporejanje državnih sredstev in subvencij, vpliva na upravljanje z državnimi sredstvi; opravlja raziskovalne in razvojne naloge; za specifične naloge oblikuje posebne projektne skupine; razvija informacijsko in svetovalno dejavnost; skrbi za promocijo in razvoj; vpeljuje in promovira novosti pri izobraževanju odraslih; vzdržuje mednarodne stike; zastopa asociacije $v$ mednarodnih združenjih; sodeluje $v$ mednarodnih projektih.

Tej pobudi bi se morala aktivno odzvati tudi država, zlasti njeni odgovorni organi, ki so bodisi po svojih službenih pristojnostih in zadolžitvah bodisi po posebnih interesih povezani $\mathrm{z}$ razvojem in delovanjem izobraževanja odraslih. Ključno vlogo ima pri tem Ministrstvo za šolstvo, znanost in šport kot odgovoren vladni resor za razvoj vzgoje in izobraževanja ter $\mathrm{s}$ tem izobraževanja odraslih. Seveda bi bilo v skladu z Unescovo deklaracijo in akcijskim načrtom tudi to, da bi takšna krovna zveza dobila tudi podporo drugih vladnih resorjev, izhajajoč iz načela, da učenja in znanja ni mogoče resorsko omejiti in da sta prisotna na vseh področjih življenja.

\section{Dr. Zoran Jelenc}

\section{LITERATURA:}

Bevc, M. (1999): Financiranje, učinkovitost in razvoj izobraževanja. Radovljica: Didakta.

CONFINTEA (1998): Izobraževanje odraslih Hamburška deklaracija in Akcijski načrt za prihodnost. Peta mednarodna konferenca o izobraževanju odraslih CONFINTEA V. Ljubljana: Urad Slovenske nacionalne komisije za Unesco in Andragoški center Slovenije.

Faure, E. (ur.) (1972): Learning to be. The World of Education Today and Tomorrow. Unesco, Paris, Harap, London.

Jelenc Z., Krajnc A., Svetina M, (1993): Znani andragogi o andragogiki. Sintezna predstavitev stališč iz raziskave in podlage za oblikovanje skupnih stališč. V Premislek o izobraževanju odraslih in razvoju (ur. Zoran Jelene in Metka Svetina). Ljubljana: Andragoški center Slovenije, str. 293-327.

Jelenc, Z. (1998): Vloga in razvoj Andragoškega društva Slovenije v obdobju 1968-1991. Ljubljana: Andragoško društvo Slovenije.

Jelenc, Z. (1999a): National Strategies of Adult Education. V Comparative Adult Education 1998. The Contribution of ISCAE to an Emerging Field of Study (ur. Jost Reischmann, Michal Bron Jr. in Zoran Jelenc). Ljubljana: International Society for Comparative Adult Education in Slovenian Institute for Adult Education, str. $147-167$.

Jelenc, Z. (2000a): Nacionalne strategije izobraževanja odraslih. Andragoška spoznanja, 2, str. 5-20. 
Jelenc, Z. (2000b): Organiziranost in delovanje združenj za izobraževanje odraslih. Primerjava modelov v evropskih državah in njihova uporabnost za delovanje Andragoškega društva Slovenije. Ljubljana: Andragoško društvo Slovenije.

Jelenc, Z. (2000): Strategija in koncepcija izobraževanja odraslih v Sloveniji. (Raziskovalno poročilo). Ljubljana: Andragoški center Slovenije.

OECD (1996): Lifelong Learning for All. Meeting of the Education Committee at Ministerial Level, 16-17 January 1996. OECD, Paris.

Uradni list RS (1996): Uradni list Republike Slovenije, št. 12, 29.2. 1996.

- Zakon o organizaciji in financiranju vzgoje in izobraževanja, str. 841-862

- Zakon o izobraževanju odraslih (1996). Uradni list RS, št. 12/1996, Ljubljana 12. 2. 1996, str. 894-900.

1 Bojazen, da bi država s svojimi ukrepi in posegi preveč vplivala, zelo radi izražajo zlasti strokovnjaki za izobraževanje odraslih (glej npr. mnenje ekspertov $v$ mednarodni primerjalni raziskavi, Jelenc idr., 1993), država pa nemalokrat takšna stališča sprejema in zlorabi tako, da skrb za izobraževanje odraslih povsem prepusti drugim.

2 Ta vprašanja pri nas temeljito proučuje raziskovalna svetnica z Inštituta za ekonomiska raziskovanja $d r$. Milena Bevc (glej npr. Bevc, 1999), Žal je to še zmeraj 'glas vpijoče ga v puščavi', čeravno bi z upoštevanjem teh spoznanj, ki se ujemajo s sodobnimi usmeritvami $v$ svetu, postopoma začeli celovito reševali gmotni položaj na področju izobraževanja in šolstva. V praksi prej ko slej ostajamo pri starih shemah, ki načelno ignorirajo nove sistemske možnosti in stem tudi finančne rešitve; te so številčnejše in bolj različne, kot se jih ta čas že zavedamo. Poleg neposredne dodelitve finančnih sredstev, ki nam daje videz, da država s tem zagotavlja pravično in brezplačno šolanje, opozarjajo strokovnjaki, denimo, tudi na mehanizme posrednega državnega financiranja izobraževalnih ustanov (npr. $z$ vavčerji), nedržavne vire dohodka izobraževalnih ustanov, oblike finančne pomoči udeležencem izobraževanja, povečanje zasebnega financiranja izobraževanja (s solninami, posojili, oblikovanjem namenskih skladov), delitev stroškov izobraževanja na različne vire, med katerimi so lahko pomembno udeleženi tudi prispevki udeležencev in tistih, ki so zainteresirani za njihovo izobraževanje, itn. Namesto vtisov, da so te možnosti manj pravične, se raziskovalno potrjujejo spoznanja, da različne možnosti praviloma povečujejo pravičnost in ugodno vplivajo na dostopnost izobraževanja.

3 O članstvu govorimo seveda hipotetično, saj se bodo posamezne organizacije in krovne zveze same odločale o morebitni včlanitvi v skupno krovno zvezo. 